\title{
Evaluation of Waste Management System at Temporary Waste Dump Site (TPS) in Urban Area of Yogyakarta
}

\author{
Idham Ibty ${ }^{1}$, M. Sigit Cahyono² \\ Universitas Proklamasi 45 \\ Email: mail.idham.ibty@gmail.com
}

\begin{abstract}
Waste has been a serious problem in all areas of Indonesia, including in urban areas of Yogyakarta (KPY). As one of the existing problems, the temporary waste dump site (TPS) requires an integrated waste management system. The objective of this research is to evaluate the condition and effectiveness of TPS in urban areas of Yogyakarta. This research uses the qualitative method, by solving the problem through the description of the object state at the time the data is taken based on the apparent facts. The main data has been obtained through the interview and field observation process, while secondary data has been obtained from documents from several institutions and other scientific references. Results of the study reveal that there are 212 units of temporary waste dump sites (TPS) in urban areas of Yogyakarta, consist of; 143 of permanent TPS, 51 containers, and 18 depots. The majority of them are located in Municipality of Yogyakarta and the fewest number are located in Bantul Region. In general, the temporary waste dumpsites in urban areas of Yogyakarta are in good condition. There's only few of them in relatively poor condition, due to the portion of waste that is not well accommodated in the TPS. Another problem is the inappropriate design of TPS, especially for containers. Consequently, the waste cannot be adequately transferred from waste vehicle to TPS. In addition, we found a new paradigm of integrated temporary waste dumpsite (TPST) operated by Non-Government Organizations, but they need adequate facilities and evaluation of the design. Including, the sustainable support from multi stakeholders, and also the plan arrangement of development to improve organizational capacity, business, and partnership in the management of the integrated temporary waste dumpsite for optimal public service.
\end{abstract}

Key words: urban areas of Yogyakarta, management waste system, temporary waste dumpsite 


\section{Introduction}

The problem of urban waste in Indonesia today is still quite difficult to solve. One of the causes is the increasing number of population, then the volume of waste also increases every day. This condition requires that the waste management become one of the national strategic issues. Therefore, several regions in Indonesia make this issue as their target of achievement from the strategic management. Public also has a great concern in this issue, especially to know the current condition and how to improve policies and develop program plans in the future [1]. The waste management system has a very important role to overcome this problem. Mistakes in choosing management strategies will cause the waste buildup of waste, and it will lead to human health problems; such as the emergence of various diseases that come from waste decay [2].

The waste management system is a process of waste management covering 5 (five) aspects or components that support each other; operational technical aspects, organizational and management aspects, legal and regulatory aspects, financing aspects, and community participation aspects. These five aspects are interrelated and can not stand alone [3]. According to SNI 19-2454-2002, waste management is an integral and integrated process into a continuous sequence, ie storage, collecting, transferring, transporting, and disposal/processing.

Storage or waste collection is a method of storing waste before it is collected, transferred, transported and disposed of in a final dumpsite or landfill (TPA). The goal is to avoid the jumble of waste and avoid the disruption to surrounding environment. The most influencing factors on the service level effectiveness are equipment capacity, shelter pattern, type and nature of materials and location of placement.

Garbage collection is a method of taking garbage from garbage can to the temporary shelters (TPS). Garbage collection patterns are basically grouped into 2 (two) patterns; individual pattern and communal pattern (SNI 19-24542002). An individual pattern is the process of garbage collection starting from the source of waste then transported to the TPS before disposal to the landfill. While in a communal pattern, the garbage collection is carried out by waste producers to a communal waste container that has been provided before or to a garbage truck that handles it from the collection point and then transported to a landfill without the transfer process.

The waste or garbage transfer is a process to move garbage from the collection process to the transport equipment to be taken to a final dump site or landfill. The place used for waste or garbage transfer is a waste removal depot equipped with container carrier, ram, office or workshop. the transfer of waste that has been disaggregated from the source, arrange not to mix again.

Garbage transport is the activity of transporting the garbage collected at the TPS (temporary dumb site) or from waste source to TPA (final dumb site). The success or failure on waste handling will depend on the transportation system that is applied by the organizer party. The ideal waste transport is by 
using a certain container truck, which is equipped with presses tool, so the garbage can be compacted 2-4 times. The purpose of garbage transport is to keep urban trash to TPA which is usually far from urban areas and settlements. While the final waste disposal site is a place that is provided to dispose of waste to be processed further. The principle of final waste disposal is destroying domestic waste at a final disposal (dump) site, so TPA is a waste processing site.

In summary, the integrated waste management process is shown in Figure 1 below,

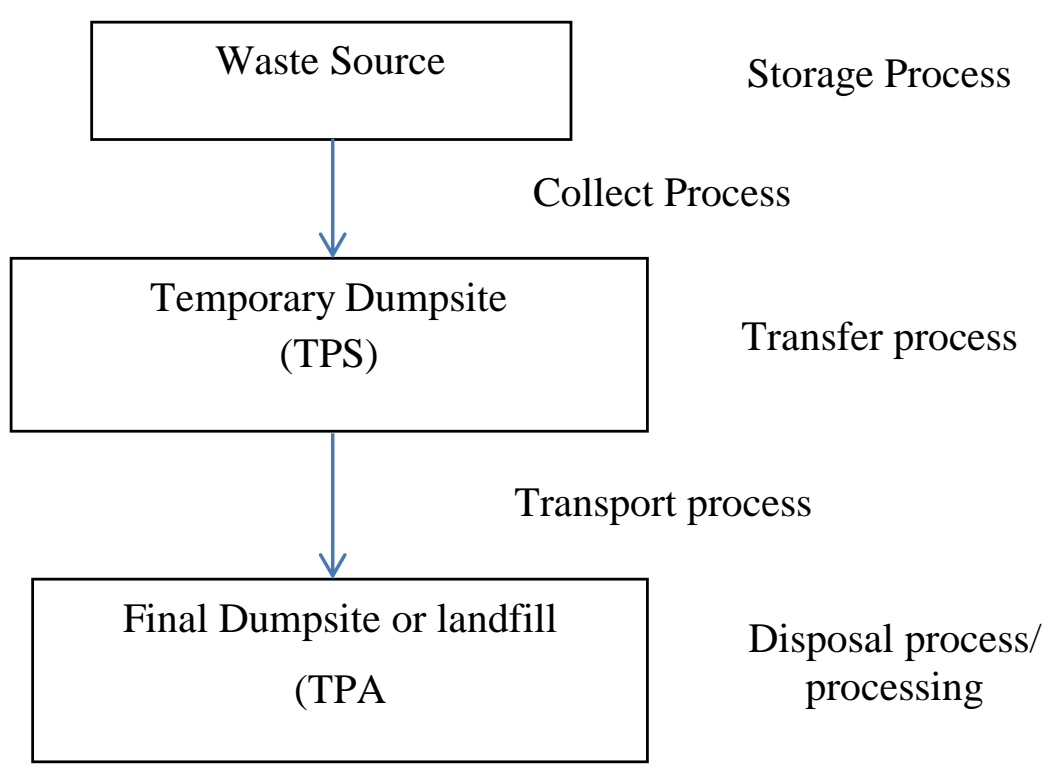

Figure 1. Integrated Waste Management Process

Integrated waste management system should be implemented in all Indonesia regions, especially in Yogyakarta.

Integrated waste management system should be applicable in all Indonesia areas, espescially in Yogyakarta. The Special Privileges regulation, which is supported by Perda (regional regulation) on Public Services, Perda on Spatial Planning and also Perda on Waste Management, should make the public services problems related to waste management as one of the strategic issues. Moreover, the supervision of public services in DIY is also run by the Ombudsman Institute of DIY [4]. Referring to Perda RT / RW DIY, the policy of Urban Area of Yogyakarta has function as a National Activity Center (PKN) covering the area of Yogyakarta City and part of Kasihan District, Sewon, Banguntapan in Bantul Regency and Depok, Ngaglik, Mlati and Gamping in Sleman District. These areas are the development of Yogyakarta's urban service system that serves other cities, such as: Berbah, Kalasan, Prambanan, Pakem, Cangkringan, Sedayu and Sentolo.

One of the challenges faced by urban areas managers in Yogyakarta is the importance of temporary shelter (TPS) positions, which are used as a medium 
of liaison between waste from its sources with the TPA. The waste management system in the TPS should be done appropriately because the mismanagement in the system will cause a negative impact on the community; such as the rotten smell, the emergence of disease vectors, as well as aesthetically factors.

The location of the Temporary Shelter (TPS) is also one of the important parameters to be considered in the waste management policy. Aremu [5] conducted an optimization study on the determination of the location of TPS placement in Ilorin, Kware State, Nigeria. In the research, the optimization is done by studying the service coverage by considering the distance to the TPS and the satisfaction of the general public. The conclusion of this research is the rise of the TPS number will improve service coverage and public satisfaction. However, an increase in the number of TPS resulted in a low utility level because the TPS would be unfilled so it was less than optimal.

Therefore, the management of TPS in an area must be done appropriately, including the placement, which should be in accordance with the needs of the needs of the area. The purpose of this research is to identify the condition and the effectiveness of waste management system at temporary shelters (TPS) in Urban Area of Yogyakarta, as the base in formulating the policy of waste management in Urban Area of Yogyakarta.

\section{Research Methodology}

The research method is a qualitative method. The study's attention lies in the problem-solving process through drawing the condition of the research object at the time the data is taken, based on the facts that appear or as it is. The research approach uses inductive reasoning with related informationgathering techniques using in-depth interviews with focus group observations and discussions as part of its valid data test [6]. Primary data collection was conducted in August 2014, especially at the TPS sites that became the object of the research.

Secondary data was taken from supporting documents in related institutions, as well as other scientific references. The data analysis is done descriptively to explain the achievement according to the description of the research problem. The data will be analyzed in-depth to produce a comprehensive research result.

\section{Results and Discussion}

\subsection{Characterization of Waste Shelters (TPS) in Urban Area of Yogyakarta}

Territorially, the waste management system in the Urban Area of Yogyakarta (KPY) consists of permanent temporary shelters (TPS), garbage containers, and garbage depots that serve as temporary waste shelters. The Integrated Waste Management Site (TPST) and Waste Recycling Site (LDUS) is a waste infrastructure at the scale of the area that has implemented a process 
of sorting and processing based on environmentally friendly. While the final part of the process of urban waste management is in the Final Disposal Site (TPA) of waste, which in accordance with DIY Regulation No. 2 / 2010, set in the Village Sitimulyo, Piyungan Subdistrict, Bantul Regency.

The specific characteristics of temporary waste shelters in urban areas of Yogyakarta are as follows:

\section{Permanent TPS}

Permanent TPS is a generally open-duty waste bin with capacity measures of 3,4 , and $24 \mathrm{~m} 3$, depending on the available space and community needs. TPS is a temporary shelter with the highest number of other forms, as many as 143 places. The number of these places is scattered in almost all areas of KPY, with details; 123 units in the city of Yogyakarta with a total capacity of $438.48 \mathrm{~m} 3,19$ units in Sleman district (total capacity $435.24 \mathrm{~m} 3$ ), and 1 unit in Bantul district with a capacity of $24 \mathrm{~m} 3$ [3]. This shows that the city of Yogyakarta has a number of "TPS" which is much more than the KPY region located in Bantul and Sleman districts. The number of permanent TPS is caused by the small land requirement, compared to other TPS so it is suitable for densely populated areas such as Yogyakarta [7].

\section{Garbage Container}

Containers are tubs of varying sizes from 4 - $24 \mathrm{~m} 3$ which are generally made of iron or steel and have an open or closed cavity called doors (pintu). Containers are not attached to the ground, so when the container is full it can be transported and replaced by another empty container. One of the container advantages is the flexibility of the place, so if needed, the transfer can be done immediately and fast. Although the size of the containers is varied, in general, the containers sized that used in Yogyakarta city are between $6 \mathrm{~m} 3$ and $12 \mathrm{~m} 3$, then it requires a larger area than the permanent TPS [7]. The total number of containers in KPY is 51 units, with details; 16 units in Yogyakarta City with a total capacity of $96 \mathrm{~m} 3,22$ units in Sleman with a total capacity of $132 \mathrm{~m} 3$, and 13 units in Bantul Regency with a capacity of $78 \mathrm{~m} 3$ [3]. This indicates that most of the TPS with container type in KPY is located in Sleman Regency, while the lowest number is in Bantul regency.

\section{Waste Depot}

Depo is the point where garbage transits, from carts into trucks to then proceed to the landfill. Depo in KPY by the majority is categorized as Type II depot with a capacity of 100 to $200 \mathrm{~m} 3$, in the form of permanent buildings equipped with climbs and parking equipment of the collectors (carts). In KPY, there are only 18 depots where the majority are located in Yogyakarta City, ie 13 units with a total capacity of 1300 m3, while in Sleman Regency has 5 depots with a total capacity 
of 800 m3. Meanwhile, in the KPY region located in Bantul District, none of the depots [3] were found. The advantages of waste depots, apart from their large capacity, the waste disposal service to the TPA can be done in one full day, depending on the level of garbage disposal of each depo [8].

The distribution of waste infrastructure in the Urban Area of Yogyakarta is shown in Figure 2 below,

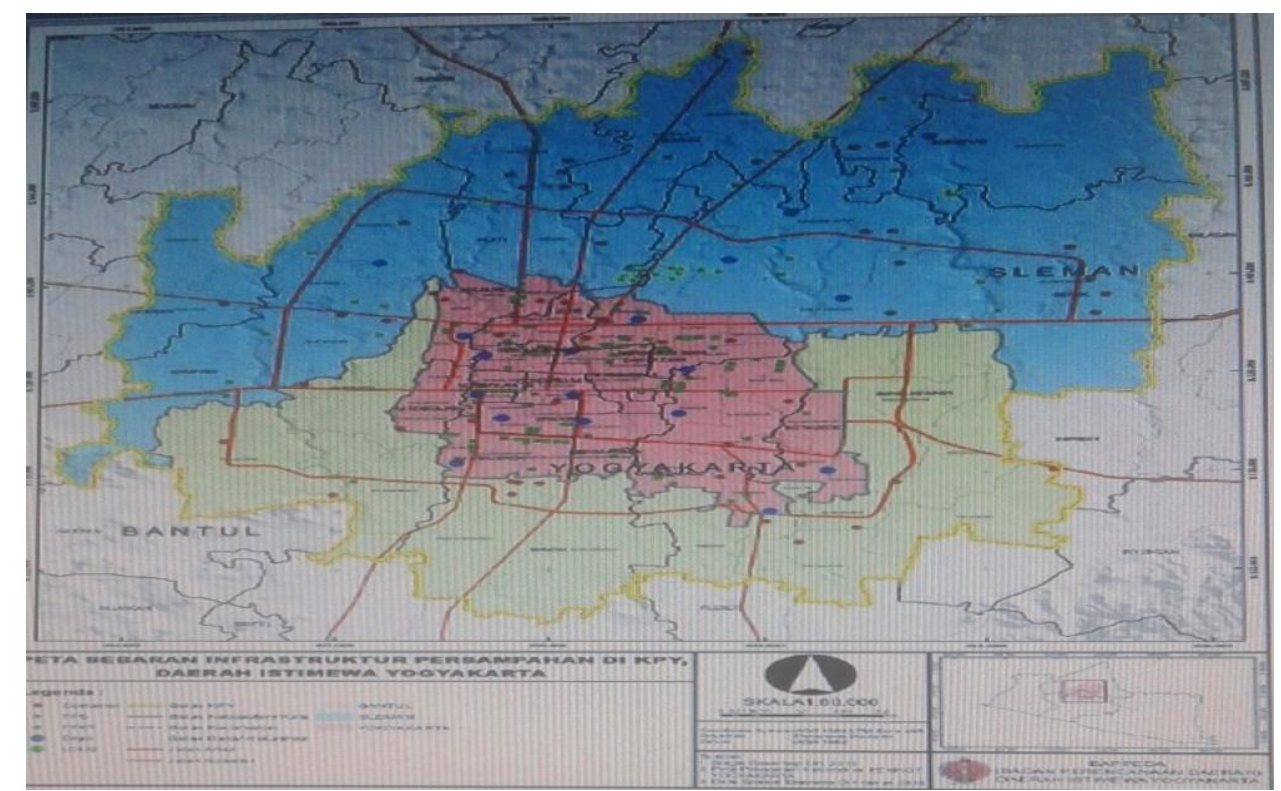

Figure 2. Map of distribution of waste infrastructure of KPY [3]

Based on the map in figure 2, it can be seen that garbage infrastructure, especially Temporary Waste Dump Site (TPS) are mostly located in Yogyakarta City, especially in central and north of Yogyakarta. While in Bantul District, there are only a few in number and placed only at some random point. This is due to the fact that the population density in Yogyakarta is bigger than Sleman and Bantul, especially in the area that is part of Yogyakarta Urban Area.

\section{a. System for Temporary Waste Dumpsite Management (TPS) of the Urban Area of Yogyakarta}

Based on the observation of several TPS in the Urban Area of Yogyakarta, almost all of the waste was disposed of by the society (directly to the TPS or transported by the garbage cart or small car) from the source to the TPS, in mixed condition. The waste is sorted by trash pickers after arriving at the TPS, where valuable waste will be sold to collectors who come to the TPS at certain times. The function of the trash picker is less significant as only a small fraction of the waste taken (on average 10\%), while the remaining are not taken will be disposed of by the garbage trucks to the TPA in Piyungan. 
Meanwhile, in relation to the garbage collection schedule, most of the garbage in TPS, whether permanent TPS, container or Depo, is taken daily by truck to be transported to the TPA. Only under certain conditions, the garbage heap will appear, especially for the type of garbage that has been sorted by trash pickers. These residual of garbage will usually be taken by the buyer every week or within a certain period in accordance with the capacity of the carrier vehicle.

Related to the condition of TPS, most of the physical TPS in KPY are in good condition, especially permanent TPS. As for containers, some units have been damaged but can still be used to accommodate temporary waste before disposal to the landfill. The poor condition of the TPS was caused by the uncomfortable design of the tub, this makes garbage disposal officer experienced the difficulties in performing their duties, as a result, the container becomes easier to get dirty and rusty. Therefore, evaluation is required for the improvement of the design of this container. In addition, the depot transfer with the waiting system, a lot of garbage is accumulated due to the coordination of the transfer time between the garbage collector and the vehicle is not on its time, so the waste management at TPS needs to be improved [3].

Another factor to consider in an urban waste management system is the number of Human Resources (HR) involved in the management. The TPS management in urban areas such as KPY requires workers in accordance with the amount of garbage disposal. A $24 \mathrm{~m} 3$ depot requires one janitor and one truck driver, while the depot with the capacity of $48 \mathrm{~m} 3$, requires two janitors and two drivers for two units of garbage trucks. And for container systems, a team consists of two janitors and one truck driver. This system is used to transport garbage up to three containers with a capacity of $6 \mathrm{~m} 3$ every day. As for the permanent TPS system, a team consists of four cleaners and one truck driver to transport garbage from 5-8 TPS, depending on the volume of daily waste disposal in the same sector.

In addition to the above mentioned TPS, the DIY Government has also built several pilot sites of Integrated Waste Management (TPST), such as TPST Umbulharjo, TPST Banguntapan, and TPST Wirokerten. TPST is intended to be used as a place for collection, sorting, reuse, recycling, processing, and final waste processing. The presence of TPST is very important because it can be used as a place to process garbage, what makes the garbages transported to Piyungan Final Disposal (dump Site) Place (TPA) is only the residue. This kind of practice for sure can extend the landfill life. The TPST is proposed by a SelfHelp Group (KSM) in the local urban village and built with the APBD of DIY. TPST facilities which have been built in the form of one unit of open buildings and one office unit. KSM in each location has proposed activities to SKPD for the completeness of the mechanical and equipment matter, including supporting infrastructures such as roads and parking places. In addition, there are also proposals for activities to improve the organizational management capacity and its efforts to the Universities. 
The research found a new paradigm of waste management owned by the KSM leaders, but not yet sufficiently and deeply socialized to other boards and regular members. The new paradigm is to think of waste as a resource that has economic value and can be utilized, for example, earmarked for energy, compost, fertilizer or for industrial raw materials. Therefore, in order for this paradigm to be realized properly, it is necessary to socialize and improve the capacity of KSM administrators and members until as of they can perform the process of waste management properly and also can produce the greatest benefit for all citizens.

\section{Conclusion}

Based on the research that has been carried out, it can be concluded that the temporary waste management system in Yogyakarta Urban Area (KPY) which has existed at this time is enough. Where the majority is located in Yogyakarta City (especially permanent TPS) and else in Bantul Regency which belongs to KPY. Meanwhile, the condition of TPS in the Urban Area of Yogyakarta is quite good, only in some locations are in poor condition. This is due to the amount of garbage that is not accommodated in the TPS, most of them are scattered outside. Another problem is the improper of TPS design, especially the containers, causing the waste transfer process from the cart into TPS cannot run properly.

TPST as a pilot project has been established but has not operated optimally since it is still completing the physical development. The leaders of KSM in which the TPST management is actively running the organization, but the new paradigm on integrated waste management has not been socialized to the board and its members. And related to the machinery and equipment issues, as well as the matter of procuring paved roads and parking lots, it is still incomplete. In addition, the technology of a good and environment-friendly garbage treatment is also being cultivated, so it has not yet produced the product.

For further study, it is necessary to evaluate the design of TPS system with TPST model in order to provide optimal service to the citizens. One of the best alternatives that need to be pursued is the utilization of organic waste management technology into compost, as well as inorganic waste into alternative energy sources. From the beginning, a TPST development plan should be developed in terms of organization, business, and partnership for its economic, social and environmental success.

\section{References}

[1] T. Morden, "Principles of Strategic Management (Third Edition)," Ashgate Publishing, Farmham, 2007. 
[2] Sodikin, "Arahan dan Manajemen Pengankutan Sampah di Kecamatan Pondok Gede," Sosio Didaktika: Social Science Education Journal, vol. 2, no. 1, pp. 50-57, 2015.

[3] A. Nugrahadi, "Evaluasi Kebijakan dan Strategi Pengelolaan Sampah di Kawasan Perkotaan Yogyakarta," Program Studi Magister Perencanaan Kota dan Daerah UGM, Yogyakarta, 2014.

[4] I. Ibty, "Keistimewaan Jogja Jamin Pelayanan Publik Secara Terpadu," in Seminar Raperda Pelayanan Publik DIY, Yogyakarta, 2012.

[5] A. S. Aremu, Optimization and Assessment of Waste Bin Locations Using Geographic Information Sysytem, Ilorin: University of Ilorin, 2011.

[6] J. W. Creswell, Research Design; Pendekatan Kualitatif, Kuantitatif, dan Mixed (third Edition), Yogyakarta: Pustaka Pelajar, 2014.

[7] T. Sari, "Optimasi Penentuan Jumlah dan Lokasi Tempat Pembuangan Sampah di Kota Yogyakarta," Jurusan Teknik Mesin dan Industri UGM, Yogyakarta, 2014.

[8] A. Haryoto, "Optimasi Penempatan Tempat Penampungan Sampah Sementara di Kota Yogyakarta," Jurusan Teknik Mesin dan Industri UGM, Yogyakarta, 2013. 